\title{
9: 34681274-34679567
}

National Cancer Institute

\section{Source}

National Cancer Institute. 9: 34681274-34679567. NCI Thesaurus. Code C41863.

Physical location of CCL19_Gene 